\title{
Penggunaan Tepung Daun Kelor (Moringa oleifera) dalam Ransum terhadap Kualitas Telur Ayam Ras Petelur dari Umur 20 Bulan
}

\author{
The Use of Moringa oleifera Leaf Flour in a Ration Against the Quality of Egg Laying \\ Chicken Eggs from the Age of 20 Months
}

\author{
I. E. Purba, Warnoto, dan B. Zain
}

Jurusan Peternakan, Fakultas Pertanian, Universitas Bengkulu

Jalan Raya W. R. Supratman, Kandang Limun, Bengkulu 38371A

Corresponding e-mail :isaelona11@gmail.com

\begin{abstract}
This study aims to evaluate the addition of Moringa oleifera leaves in rations on the quality of 20-month-old laying eggs. The research was held on July 22, 2018 until September 172018 located at the Commercial Zone Animal Laboratory (CZAL) and Laboratory of Animal Husbandry, Faculty of Agriculture, University of Bengkulu. The study used a completely randomized design (CRD) with 4 treatments and 10 replications, each replication consisted of 1 chicken. The chicken were brown laying chicken aged 20 months. The total number of chicken used were 40 which were kept in batteray cages. The treatment consisted of $\mathrm{P} 0$ without the Moringa leaf flour, P1 1.5\%, P2 3\%, and P3 4.5\%. The variables observed were egg weight, egg yolk index, egg white index, haugh unit, yolk brightness, yolk weight, and shell thickness. The data obtained were analyzed by variance (ANOVA), if there was a significant effect $(\mathrm{P}<0.05)$ the detail testing used the Duncan's Multiple Range Test (DMRT). The result of the research concluded the Moringa leaf flour until $4.5 \%$ in the ration increased the yolk brightness, the higher use in rations increases yolk brightness, but conversely decreases index of egg white and haugh unit. The use of Moringa leaf flour in rations of $1.5 \%, 3 \%$, and $4.5 \%$ did not affect egg weight, yolk weight, yolk index and the thickness of eggshell aged 20 months.
\end{abstract}

Key words: Laying chicken, Moringa oleifera, egg quality

\begin{abstract}
ABSTRAK
Penelitian ini bertujuan untuk mengevaluasi penggunaan tepung daun kelor ( Moringa oleifera) dalam ransum terhadap kualitas telur ayam ras petelur umur 20 bulan. Penelitian ini dilaksanakan pada tanggal 22 Juli 2018 sampai 17 September 2018 berlokasi di Comercial Zone Animal Laboratory (CZAL) dan Laboraturium Jurusan Peternakan Fakultas Pertanian Universitas Bengkulu. Penelitian menggunakan Rancangan Acak Lengkap ( RAL ) dengan 4 perlakuan dan 10 ulangan, masing-masing ulangan terdiri 1 ekor ayam. Ayam yang digunakan adalah ayam ras petelur cokelat umur 20 bulan. Total ayam yang digunakan adalah 40 ekor yang dipelihara di kandang batteray. Perlakuan terdiri P0 tanpa penggunaan tepung daun kelor, P1 1.5\%, P2 3\%, dan P3 4.5\%. Variabel yang diamati adalah berat telur, indeks kuning telur, indeks putih telur, haugh unit, kecerahan yolk, berat yolk, dan tebal kerabang. Daata yang diperoleh dianalisis dengan sidik ragam (ANOVA), bila terdapat pengaruh nyata $(\mathrm{P}<0,05)$ dilakukan uji lanjut dengan Duncan's Multiple Range Test (DMRT).Hasil penelitian dapat disimpulkan bahwa penggunaan tepung daun kelor dalam ransum sampai level $4.5 \%$ dapat meningkatkan kecerahan yolk, semakin tinggi penggunaan dalam ransum semakin meningkat kecerahan yolk, tetapi sebaliknya semakin menurunkan indeks putih telur dan haugh unit. Penggunaan tepung daun kelor pada ransum $1.5 \%, 3 \%$, dan $4.5 \%$ tidak mempengaruhi berat telur, berat yolk, indek yolk dan tebal kerabang telur ayam ras petelur coklat umur 20 bulan.
\end{abstract}

Kata kunci : Ayam ras petelur, Moringa oleifera, kualitas telur

\section{PENDAHULUAN}

Ayam petelur merupakan salah satu ternak unggas yang cukup potensial di Indonesia. Ayam petelur dibudidayakan khusus untuk menghasilkkan telur secara komersial. Saat ini terdapat 2 kelompok ayam petelur yaitu tipe ayam medium dan tipe ringan. Tipe mediium umumnya bertelur dengan kerabang coklat sedangkan tipe ringan bertelur dengan kerabang putih (North dan Bell 1990). Konsumsi telur lebih besar dari pada konsumsi hasil ternak lainnya, karena mudah diperoleh dan harganya relatif 
murah, sehingga terjangkau bagi masyarakat yang mempunya daya beli rendah (Saliem et al., 2001).

Telur memiliki kandungan gizi yang lengkap mulai dari protein, lemak, vitamin, dan mineral. Meskipun demikian telur juga mudah mengalami penurunan kualitas yang disebabkan oleh kontanminasi mikroba, kerusakkan secara fisik, serta penguaapan air dan gas-gas seperti karbondioksida, amonia, nitrogen, dan hydrogen sulfide dari dalam telur (Romanoff dan Romanoff,1963).

Penggunaan bahan pakan yang berkualitas diperlukan untuk meningkatkan produksi ternak. Pakan komersial yang berkualitas sangat tergantung pada harga bahan baku pakan yang diimpor sehingga rawan terhadap kenaikan harga, oleh karena itu, diperlukan langkah alternatif untuk menekan biaya pakan namun tetap mempertahankan kualitas pakan dan penampiilan produksi ternak tetap tinggi. Salah satu langkah yang dapat dilakukan untuk meningkatkkan penampilan produksi ternak adalah dengan tetap mempertahankan kualitas dan kuantitas pakan dan menambahkan feed additives dalam pakan. Tanaman obat dan rempah merupakan salah satu jenis komoditi pertanian yang memiliki prospek cukup cerah untuk dikembangkan. Tumbuhan yang berpotensi untuk obat (herbal), cukup banyak jenisnya dan belum banyak dimanfaatkkan. Pengetahuan tradisional tentang penmanfaatan tumbuhan sangat penting artinya, karena akan menambah keanekaragaman sumeberdaya nabati dan merupakan dasar botani ekonomi maupun botani terapan lainnya (Soekarman dan Riswan, 1992).

Salah satu solusi praktis untuk beberapa masalah di bidang perunggasan di daerah tropis adalah memperhatikan kebutuhan gizi unggas dan komposisi nutrisi dari pakan yang tersedia dalam pemeliharaan untuk kebutuhan produksi. Langkah yang paling logis untuk diiambil yaitu memecahkan masalah kekurangan pasokan bahan baku pakan dengan upaya mengarahkan peternak untuk menmanfaatkan tanaman dan produk olahan limbah untuk dijadikan bahan pakan unggas. Tumbuhan kelor merupakan salah satu tanaman yang dapat dimanfaatkan dalam penyusunan ransum unggas. Tanaman ini selain menjadi sumber vitamin dan asam amino yang baik, memilikii kegunaan di bidang medis sebagai obat (Banjo, 2012).

Kelor merupakan tanaman yang sangat mudah tumbuh di berbagai daerah dan dapat dikembangbiakkan secara vegetatif (stek) maupun generatif (benih). Sebagai tanaman legum, kelor dapat digunakan sebagai sumber pakan yang baik bagi ternak. Hal ini dikarenakan daun kelor telah diilaporkan menjadi sumber pangan yang kaya $\beta$-karoten, protein, vitamin $\mathrm{C}$, kalsium, kalium, dan menjadi sumber makanan yang baik sebagai antioksiidan alami karena adanya berbagai jenis seniyawa antioksidan seperti asam askorbat, flavonoid, fenolat dan karotenoid (Krisnadi, 2015).

Daun kelor belum banyak digunakan dalam pakan ternak terutama untuk pakan unggas. Tanaman kelor merupakan tanaman perdu yang banyak dijumpai di Indonesia sebagai tanaman pagar yang mempunyai banyak manfaat. Daun dan buah kelor telah lama digunakan oleh masyarakat sebagai sayur. Hasil penelitian yang dilakukan di Afrika menunjukkan bahwa daun kelor mengandung vitamin $\mathrm{C}$ tujuh kali lebih banyak dari buah jeruk, mengandung empat kali kalsium lebih banyak dari susu, empat kali vitamin A dalam wortel, dua kali protein dalam susu dan tiga kali potasium dalam pisang (Analysa, 2007).

Tepung daun kelor memiliki beberapa zat hipotensif, antikanker, dan antibakterial antara lain, niacimicin, pterygospermin. Selain itu daun kelor juga memiliki zat antioksidan antara lain sitosterol dan glucopyranoside. Daun kelor juga sebagai suplemen yang mempunyai nilai gizi tinggi dan dianggap sebagai sumplemen protein dan kalsium. Dari berbagai penelitian dilaporkan bahwa pada daun kelor terdapat konmposisi vitamin A, B,C, dan kalsium, zat besi dan protein yang tinggi (Sarjono, 2008).

Suhada (2016) melaporkan, penggunaan $5 \%$ dan $10 \%$ tepung daun kelor 
berpengaruh nyata meningkatkan skor warna kuning telur puyuh ( $>10$ skala Roche) tetapi, tidak mempengaruhi bobot telur, indeks telur, nilai haugh unit, persen bobot kerabang, persen bobot albumen, dan persen bobot kuning telur. Berdasarkan hal tersebut perlu dilakukan penelitian penggunaan daun kelor dalam ransum ayam ras petelur terhadap kualitas telur dengan harapan akan mendapat hasil yang baik. Penelitian ini bertujuan untuk mengevaluasi penggunaan tepung daun kelor ( Moringa oleifera) dalam ransum terhadap kualitas telur ayam ras petelur dari umur 20 bulan. Diduga penggunaan tepung daun kelor ( Moringa oleifera) sampai level $4,5 \%$ dapat meningkatkan kualitas telur ayam ras petelur dari umur 20 bulan.

\section{METODE PENELITIAN}

Penelitian dilaksanakan pada tanggal 22 Juli 2018 sampai 17 September 2018 berlokasi di Comercial Zone Animal Laboratory (CZAL) dan Laboraturium Jurusan Peternakan Fakultas Pertanian Universitas Bengkulu.

Alat yang digunakan selama penelitian adalah timbangan analitik, meja kaca, yolk saperator, jangka sorong, kaki tiga, mikrometer sekrup, yolk colour fan, tempat pakan, tempat minum, blender, alat tulis, ember, penggaris, nampan, cawan petri dan peralatan lainnya yang dibutuhkan.

Bahan yang digunakan adalah ayam ras petelur dari umur 20 bulan sebanyak 40 ekor, 40 butir telur segar, tepung daun kelor, dedak, jagung giling, mineral mix, KLK, air minum.

\section{Pembuatan Tepung Daun Kelor}

Daun kelor ( Moringa oleifera) yang digunakan pada saat penelitian didapat dari pagar kebun warga. Pembuatan tepung daun kelor dilakukan dengan mengeringanginkan lalu dikeringkan dibawah sinar matahari hingga kering. Setelah kering, daun kelor kemudian digiling meggunakan blender sehingga didapat tepung daun kelor.

\section{Persiapan Kandang}

Sebelum penelitian dilakukan, kandang sudah harus dipersiapkan terlebih dahulu mulai dari kelengkapan kandang batteray seperti tempat minum dan tempat pakan, melakukan sanitasi, menyiapkan susunan ransum yang akan digunakan, serta menyiapkan segala kebutuhan yang diperlukan selama penelitian.

\section{Adaptasi Ternak}

Sebelum perlakuan, ayam yang digunakan untuk penelitian akan diadaptasi selama 7 hari dengan ransum perlakuan. Adaptasi dilakukan agar saat penelitian ayam tidak stres saat diberikan pakan penelitian sehingga diperlukan pengadaptasian pakan penelitian kepada ternak.

\section{Pelaksaan Penelitian}

Penelitian dilakukan selama 8 minggu dengan menggunakan ayam ras petelur umur 20 bulan. Air minum diberi ad libitum dan diberi pakan sebanyak 2 kali sehari yaitu pada pagi dan sore hari. Kandungan gizi bahan penyusun ransum dapat dilihat pada tabel 1.

Table 1. Kandungan gizi bahan penyusun ransum.

\begin{tabular}{lcccccc}
\hline \multicolumn{1}{c}{ Bahan } & PK & LK & SK & Ca & P & $\begin{array}{c}\text { ME } \\
(\%)\end{array}$ \\
& 8,5 & 4.2 & 12 & 0,2 & 1,0 & 1810 \\
\hline Dedak $^{\text {a) }}$ & 8.9 & 4 & 2,2 & 0,02 & 0,23 & 3321 \\
Jagung kuning $^{\text {a) }}$ & 33 & 6,3 & 9,83 & 10,8 & 1,28 & 2700 \\
KLK $^{\text {( ) }}$ & - & - & - & 32 & 10 & - \\
Mineral Mix $^{c)}$ & 27,67 & 3,70 & 5,31 & 2,09 & 0,67 & 2303 \\
TDK $^{\text {d) }}$ & &
\end{tabular}

Sumber : a) Hartadi et al. (2005 ), b) Label KLK , c) Label Mineral Mix d) Sari (2017) 


\section{Komposisi Ransum}

Formulasi ransum dan kandungan nutrisi yang digunakan selama penelitian dapat dilihat pada tabel 2 .

Tabel 2. Formulasi ransum dan kandungan nutrisi yang digunakan

\begin{tabular}{lcccc}
\hline \multicolumn{1}{c}{ Bahan } & P0 & P1 & P2 & P3 \\
\hline Dedak & 22 & 21,5 & 21 & 20 \\
Jagung Kuning & 41,5 & 40,5 & 39,5 & 39 \\
KLK & 35 & 35 & 35 & 35 \\
Mineral Mix & 1,5 & 1,5 & 1,5 & 1,5 \\
Tepung Daun Kelor & 0 & 1,5 & 3 & 4.5 \\
\hline Total & 100 & 100 & 100 & 100 \\
\hline PK (\%) & 17,11 & 17,4 & 17,7 & 18 \\
ME ( kkal/ kg) & 2721 & 2714 & 2706 & 2706 \\
LK (\%) & 4,8 & 4,78 & 4,8 & 4,77 \\
SK (\%) & 6,99 & 6,99 & 6,99 & 6,93 \\
Ca (\%) & 4,31 & 4,34 & 4,37 & 4,40 \\
P (\%) & 0,91 & 0,91 & 0,92 & 0,91 \\
\hline
\end{tabular}

\section{Rancangan Penelitian}

Penelitian ini menggunakan

Rancangan Acak Lengkap (RAL) dengan 4 perlakuan dan 10 ulangan dimana masingmasing ulangan terdiri dari 1 ekor ayam. Ayam yang digunakan adalah ayam ras petelur cokelat dari umur 20 bulan. Total ayam yang digunakan adalah 40 ekor ayam ras petelur cokelat yang dipelihara di kandang batteray. Perlakuan dibedakan berdasarkan persentase tepung daun kelor yang digunakan, yaitu :

P0 = Ransum kontrol (tidak menggandung tepung daun kelor).

$\mathrm{P} 1=$ Ransum mengandung 1,5\% tepung daun kelor.

$\mathrm{P} 2=$ Ransum mengandung $3 \%$ tepung daun kelor.

P3 = Ransum mengandung 4,5\% tepung daun kelor.

\section{Variabel yang Diamati}

\section{Berat Telur}

Berat telur diperoleh dengan menimbang telur dengan timbangan digital dalam satuan gram. Sampel terdiri dari 4 perlakuan dan 10 ulangan, setiap ulangan digunakan 1 butir telur untuk ditimbang, sehingga telur yang digunakan untuk uji kualitas telur 40 butir.

\section{Warna Yolk}

Skor warna yolk (kuning telur) didapat dengan membandingkan warna yolk dengan warna kuning pada yolk colour fan yang dilakukan setiap dua minggu sekali selama penelitian.

\section{Berat Yolk}

Berat yolk diperoleh dengan memisahkan putih telur dengan yolk menggunakan yolk saperator, setelah yolk dan putih telur terpisah kemudian yolk ditimbang menggunakan timbanagn digital.

\section{Indeks Yolk}

Indeks yolk adalah perbandingan tinggi kuning telur dengan garis tengah kuning telur. Selama penelitian, diameter kuning telur diukur hanya sekali dan satu arah, dapat diukur dengan jangka sorong dan dihitung dengan rumus ( Koswara, 2009 ) :

$$
\text { Indeks yolk }=\frac{\text { Tinggi Yolk }}{\text { Garis Tengah Yolk }}
$$

\section{Indeks Albumen}

Indeks putih telur adalah perbandingan tinggi putih telur kental dengan garis tengahnya. Selama penelitian, diameter putih telur kental diukur hanya 
sekali dan satu arah, dapat diukur dengan menggunakan jangka sorong dan dihitung menggunakan rumus (Koswara, 2009) :

$$
\text { Indeks Albumen }=\frac{\text { Tinggi Albumen Kental }}{\text { Rata-Rata Garis Tengah Albumen }}
$$

\section{Haugt Unit}

Haugt unit (HU) adalah ukuran kualitas telur bagian dalam yang didapat dari hubungan antara tinggi putih telur dengan bobot telur. Nilai HU dihitung menurut Austic dan Nesheim (1990) dengan menggunakan rumus :

$$
\text { Nilai HU }=100 \log \left(\mathrm{H}+7,57-1,75 \cdot \mathbf{W}^{0,37}\right)
$$

Keterangan :

$\mathrm{HU}=$ Haugt Unit

$\mathrm{H}=$ Tinggi Putih Telur (mm)

$\mathrm{W}=$ Berat Telur $(\mathrm{g})$

\section{Tebal Kerabang Telur}

Tebal kerabang telur didapat dengan mengukur tebal kerabang pada 3 bagian yaitu : kerabang bagian lancip, kerabang bagian tumpul (rongga udara), dan kerabang bagian tengah dengan jangka sorong dalam satuan mm. Tebal kerabang diukur dengan menggunakan rumus sebagai berikut (Romanoff dan Romanoff, 1963).

Keterangan :

$$
\mathrm{TK}=\frac{\mathrm{t} 1+\mathbf{t} 2+\mathbf{t} 3}{3}
$$

$\mathrm{TK}=$ tebal kerabang

$\mathrm{t} 1, \mathrm{t} 2, \mathrm{t} 3=$ tebal kerabang pada ujung tumpul, tengah dan lancip.

\section{HASIL DAN PEMBAHASAN}

\section{Berat Telur}

Ukuran telur merupakan faktor penting yang dapat menentukan penerimaan harga dalam aspek pemasaran. Berat telur ayam ras berdasarkan SNI 01-3926-2006 dibagi kedalam 4 kelompok, yaitu ekstra (>60 gr), (56-60 gr), sedang (51-55 gr), kecil (46-50 gr), dan ekstra kecil ( $<46$ gr). Ratarata berat telur ayam ras dari hasil penelitian dengan perlakuan penggunaan tepung daun kelor (TDK) dapat dilihat pade Tabel 3.

Hasil analisis ragam menunjukkan bahwa penggunaan tepung daun kelor berpengaruh tidak nyata $(\mathrm{P}>0,05)$ terhadap berat telur. Berat suatu telur akan mempengaruhi kandungan nutrient dalam telur. Rataan berat telur selama penelitian $\mathrm{P} 0$ $(64,20 \pm 0,80), \quad \mathrm{P} 1 \quad(64,18 \pm 0,97), \quad \mathrm{P} 2$ $(64,80 \pm 0,88), \quad$ P3 $(62,55 \pm 0,85)$. Tabel 4 menunjukkan rataan berat telur yang dihasilkan termasuk dalam kelompok ekstra (>60 gr), (SNI 2006).

Wahyu (1985) menjelaskan bahwa kualitas pakan yang baik dalam hal ini kandungan protein, asam amino dan asam linoleat akan mempengaruhi bobot telur, karena pakan dengan kualitas yang baik akan menghasilkan telur yang besar. Daun kelor sangat kaya akan nutrisi diantaranya kalsium, besi, protein, vitamin $\mathrm{A}$, vitamin $\mathrm{B}$, dan vitamin C (Misra \& Misra 2014; Oluduro, 2012; Ramachandran, et al., 1980).

Tabel 3. Rata-rata berat telur pada masing-masing perlakuan minggu ke 2, 4, 6, 8 dan selama penelitian.

\begin{tabular}{ccccccc}
\hline Minggu & P0 & P1 & P2 & P3 & Ket & Satuan \\
\hline 2 & 63,17 & 63,65 & 63,86 & 63,47 & ns & gram \\
4 & 64,04 & 63,09 & 64,89 & 61,71 & ns & gram \\
6 & 65,04 & 64,82 & 65,97 & 61,95 & ns & gram \\
8 & 64,54 & 65,16 & 64,52 & 63,08 & ns & gram \\
\hline Rata-rata & 64,20 & 64,18 & 64,80 & 62,55 & ns & gram \\
\cline { 2 - 6 } Sd & 0,80 & 0,97 & 0,88 & 0,85 & & \\
\hline
\end{tabular}

Keterangan: $\mathrm{P} 0=$ ransum kontrol, $\mathrm{P} 1=$ Penggunaan 1,5\% TDK dalam ransum. $\mathrm{P} 2=$ Penggunaan $3 \%$ TDK dalam ransum dan $\mathrm{P} 3=$ Penggunaan $4,5 \%$ TDK dalam ransum. $\mathrm{ns}=$ tidak berbeda nyata $(\mathrm{P}>0,05)$. 
Selain itu, daun kelor juga mengandung asam amino, antara lain asam aspartat, asam glutamat, alanin, valin, leusin, isoleusin, histidin, venilalalin, triftopan, sistein dan methionin (Simbolon et al., 2007). Berat telur dipengaruhi beberapa faktor yaitu : jenis kelamin, perubahan musim, berat tubuh induk dan ransum yang diberikan (Sarwono, 2001).

\section{Berat Yolk}

Kuning telur merupakan bagian yang penting dari telur karena mengandung banyak lemak, vitamin dan mineral. Nilai rataan berat yolk ditampilkan pada Tabel 4 .

Hasil analisis ragam menunjukkan bahwa penggunaan tepung daun kelor berpengaruh tidak nyata $(\mathrm{P}>0,05)$ terhadap berat yolk. Menurut Soeparno et al.,(2011), persentase kuning telur mencapai $25-32 \%$. Rataan persentase kuning telur yang dihasilkan berada pada kisaran dibawah normal P0 (22,11 \pm 0.25$), \mathrm{P} 1(23,23 \pm 0.36), \mathrm{P} 2$
$(22,42 \pm 0.32)$, dan P3 $(22,92 \pm 0.31)$. Menurut Triyuanta (1998) berat kuning telur dipengaruhi berat telur, berat telur yang berat mempunyai kuning telur lebih berat, sedangkan menurut Anggorodi (1997), faktor yang mempengaruhi ukuran kuning telur ayam adalah asupan asam linoleat.

Berat kuning telur dipengaruhi oleh lama peneluran, rata-rata kuning telur yang dihasilkan dari peneluran jangka pendek maupun jangka panjang, umur, dan telur yang mempunyai berat yolk lebih kecil proporsi kuning telur lebih kecil juga (Stadelman dan Cotteril, 1995).

\section{Warna Yolk}

Warna kuning telur merupakan salah satu cara menentukan kualitas telur dari sudut pandang konsumen. Konsumen lebih menyukai warna kuning telur yang lebih kuning. Warna yolk dari semua perlakuan dapat dilihat pada Tabel 5.

Tabel 4. Rata-rata berat yolk pada masing-masing perlakuan minggu ke 2, 4, 6, 8 dan selama penelitian.

\begin{tabular}{ccccccc}
\hline Minggu Ke & P0 & P1 & P2 & P3 & Ket & Satuan \\
\hline 2 & 22,41 & 23,42 & 22,78 & 22,59 & ns & $\%$ \\
4 & 22,18 & 23,63 & 22,37 & 23,27 & ns & $\%$ \\
6 & 21,84 & 23,08 & 22,01 & 23,06 & ns & $\%$ \\
8 & 22,00 & 22,80 & 22,52 & 22,74 & ns & $\%$ \\
\hline Rataan & 22,11 & 23,23 & 22,42 & 22,92 & ns & $\%$ \\
Sd & 0,25 & 0,36 & 0,32 & 0,31 & & \\
\hline
\end{tabular}

Keterangan: $\mathrm{P} 0=$ ransum kontrol, $\mathrm{P} 1=$ Penggunaan $1,5 \%$ TDK dalam ransum. $\mathrm{P} 2=$ Penggunaan $3 \%$ TDK dalam ransum dan $\mathrm{P} 3=$ Penggunaan $4,5 \%$ TDK dalam ransum. $n s=$ tidak berbeda nyata $(\mathrm{P}>0.05)$.

Tabel 5. Rata-rata skor warna yolk pada masing-masing perlakuan minggu ke 2, 4, 6, 8 dan selama penelitian.

\begin{tabular}{cccccc}
\hline Minggu Ke & P0 & P1 & P2 & P3 & Ket \\
\hline 2 & 8,10 & 8,50 & 8,60 & 8,40 & $\mathrm{~ns}$ \\
4 & 8,60 & 8,10 & 9,00 & 9,30 & $\mathrm{~ns}$ \\
6 & 8,40 & 9,40 & 9,67 & 10,40 & $\mathrm{~ns}$ \\
8 & 8,90 & 9,80 & 9,56 & 10,50 & $\mathrm{~ns}$ \\
\hline Rata-rata & $8,50^{\mathrm{b}}$ & $8,95^{\mathrm{ab}}$ & $9,18^{\mathrm{a}}$ & $9,65^{\mathrm{a}}$ & $* *$ \\
\cline { 2 - 6 } Sd & 0,34 & 0.79 & 0,50 & 0,99 & \\
\hline
\end{tabular}

Keterangan: $\mathrm{P} 0=$ ransum kontrol, $\mathrm{P} 1=$ Penggunaan $1,5 \%$ TDK dalam ransum. $\mathrm{P} 2=$ Penggunaan $3 \%$ TDK dalam ransum dan $\mathrm{P} 3=$ Penggunaan $4,5 \%$ TDK dalam ransum. $* *=$ sangat berbeda nyata $(\mathrm{P}<0,01)$. 
Hasil analisis ragam menunjukkan penggunaan tepung daun kelor dalam ransum berpengaruh sangat nyata $(<0,01)$ terhadap warna yolk. Hasil uji lanjut menunjukkan P0 berbeda nyata dengan P2 dan P3 tetapi tidak berbeda nyata dengan P1. P1, P2 dan P3 tidak berbeda nyata $(\mathrm{P}>0,05)$. Rataan skor warna kuning telur selama penelitian $\mathrm{P0}$ $(8,50 \pm 0,34), \mathrm{P} 1(8,95 \pm 0,79), \mathrm{P} 2(9,18 \pm 0,50)$, dan P3 $(9,70 \pm 0,99)$. Analisis ragam menunjukkan semakin banyak tepung daun kelor didalam ransum, intensitas warna kuning telur semakin baik.

Skor kuning telir yang dihasilkam pada penelitian ini cukup tinggi, Amrullah (2003) menyatakan, warna kuning telur mencapai skor 7-8 skala Roche, telur digolongkan ke dalam kualitas baik. Warna kuning telur dipengaruhi oleh kandungan senyawa karotenoid yang banyak terdapat pada tumbuhan. Sujana (2006) menyatakan bahwa pakan mempengaruhi warna kuning telur, bahan pakan yang mengandung pigmen karotenoid terutama pigmen betakaroten dan xantofil.

\section{Indeks Kuning Telur (IKT)}

Indeks kuning telur berkaitan dengan bentuk ideal telur yang disukai konsumen. Indeks kuning telur merupakan perbandingan antara tinggi kuning telur dengan diameter kuning telur. Indeks kuning telur segar berkisar antara 0,33-0,50 (Buckle et al.,1985). Indeks kuning telur dari hasil penelitian penggunaan tepung daun kelor dapat dilihat pada Tabel 6 .
Hasil analisis ragam menunjukkan bahwa penggunaan tepung daun kelor terhadap indeks kuning telur berpengaruh tidak nyata $(P>0,05)$. Nilai rataan indeks kuning telur selama penelitian yaitu $\mathrm{P} 0$ $(0,40 \pm 0,03), \mathrm{P} 1(0,40 \pm 0,01), \mathrm{P} 2(0,38 \pm 0,04)$, P3 $(0,40 \pm 0,01)$. Rataan indeks kuning telur yang dihasilkan tergolong normal. Menurut Buckle, et al., (1985) bahwa indeks kuning telur segar berada pada kisaran 0,33-0,50 dengan nilai rata-rata 0,42 . Menurut Argo (2013) indeks kuning telur dipengaruhi oleh protein, lemak, dan asam amino esensial. Sudaryani (2006) menyatakan indeks kuning telur merupakan indeks mutu kesegaran yang diukur dari tinggi dan diameter kuning telur. Selanjutnya Bhale et al., (2003) menyatakan bahwa nilai indeks yolk digunakan untuk menentukan kesegaran telur. Indeks yolk mengindikasikan penurunan progresif dari fungsi membran vitelin pada telur, semakin kecil indeks yolk maka mutu telur semakin berkurang.

\section{Indeks Putih Telur (IPT)}

Indeks putih telur dari semua perlakuan penggunaan tepung daun kelor dapat dilihat pada Tabel 7. Hasil analisis ragam menunjukkan bahwa penggunaan tepung daun kelor berpengaruh tidak nyata terhadap indeks putih telur $(\mathrm{P}>0,05)$. Ransum dengan penggunaan tepung daun kelor dengan level $3 \%$ dan $4,5 \%$ lebih rendah indeks putih telur dibandingkan level $1,5 \%$ dan dengan tanpa tepung daun kelor $(0 \%)$.

Tabel 6. Rata-rata indeks kuning telur pada masing-masing perlakuan minggu ke 2, 4, 6, 8dan selama penelitian.

\begin{tabular}{cccccc}
\hline MingguKe & P0 & P1 & P2 & P3 & Ket \\
\hline 2 & 0,37 & 0,41 & 0,32 & 0,38 & $\mathrm{~ns}$ \\
4 & 0,40 & 0,40 & 0,36 & 0,41 & $\mathrm{~ns}$ \\
6 & 0,44 & 0,41 & 0,40 & 0,40 & $\mathrm{~ns}$ \\
8 & 0,41 & 0,39 & 0,42 & 0,40 & $\mathrm{~ns}$ \\
\hline Rataan & 0,40 & 0,40 & 0,38 & 0,40 & $\mathrm{~ns}$ \\
Sd & 0,03 & 0,01 & 0,04 & 0,01 & \\
\hline
\end{tabular}

Keterangan: $\mathrm{P} 0=$ ransum kontrol, $\mathrm{P} 1=$ Penggunaan 1,5\% TDK dalam ransum. P2=Penggunaan 3\% TDK dalam ransum dan $\mathrm{P} 3=$ Penggunaan $4,5 \%$ TDK dalam ransum. $\mathrm{ns}=$ tidak berbeda nyata $(\mathrm{P}>0,05)$. 
Tabel 7. Rata-rata indeks putih telur pada masing-masing perlakuan minggu ke 2, 4, 6, 8 dan selama penelitian.

\begin{tabular}{cccccc}
\hline MingguKe & P0 & P1 & P2 & P3 & Ket \\
\hline 2 & 0,07 & 0,07 & 0,05 & 0,07 & ns \\
4 & 0,09 & 0,08 & 0,06 & 0,06 & $*$ \\
6 & 0,09 & 0,09 & 0,07 & 0,06 & ns \\
8 & 0,08 & 0,07 & 0,07 & 0,07 & ns \\
\hline Rataan & 0,08 & 0,08 & 0,06 & 0,06 & ns \\
Sd & 0,01 & 0,01 & 0,01 & 0,01 & \\
\hline
\end{tabular}

Keterangan: $\mathrm{P} 0=$ ransum kontrol, $\mathrm{P} 1=$ Penggunaan $1,5 \%$ TDK dalam ransum. $\mathrm{P} 2=$ Penggunaan $3 \%$ TDK dalam ransum dan $\mathrm{P} 3=$ =Penggunaan 4,5\% TDK dalam ransum. ns= tidak berbeda nyata. $*=$ berbeda nyata $(\mathrm{P}=<0.05)$.

Nilai rataan selama penelitian $\mathrm{P} 0$ $(0,08 \pm 0,02), \mathrm{P} 1(0,08 \pm 0,01), \mathrm{P} 2(0,06 \pm 0,01)$, $\mathrm{P} 3(0,06 \pm 0,03)$. Indeks puth telur yang dihasilkan selama penelitian tergolong dalam mutu III rataan indeks albumen 0,050-0,091 (SNI, 2006), hal ini disebabkan oleh lama penyimpanan telur. Kualitas putih telur sebagian besar bergantung pada jumlah ovomucin yang disekresi oleh magnum. Ovomucin merupakan bahan yamg menentukan tinggi putih telur dan pembentukan ovomucin tergantung pada konsumsi protein (Yuanta, 2002).

\section{Haugh Unit (HU)}

Haugh unit merupakan satuan yang digunakan untuk mengetahui kesegaran isi telur, terutama pada bagian putih telur.
Rataan haugh unit dari semua perlakuan dapat dilihat pada Tabel 8 .

Hasil analisis ragam menunjukkan bahwa penggunaan tepung daun kelor berpengaruh tidak nyata $(\mathrm{P}>0,05)$ terhadap haugh unit. Rataan haugh unit selama penelitian P0 $(76,97 \pm 8,16)$, P1 $(78,35 \pm 4,35)$, P2 $\quad(69,77 \pm 5,07), \quad$ P3 $\quad(63,90 \pm 5,29)$. Berdasarkan hasil analisis ragam, haugh unit telur yang dihasilkan selama penelitian P0 dan P1 termasuk kedalam mutu I dengan nilai $\mathrm{HU}>72$, P2 dan P3 tergolong mutu II dengan nilai HU 62-72 (SNI, 2006). Semakin tinggi nilai haugh unit suatu telur menunjukkan kualitas telur semakin baik (Sudaryani,2006). Hasil penelitian menunjukkan semakin tinggi penggunaan tepung daun kelor nilai HU semakin turun.

Tabel 8 Rata-rata hauhg unit pada masing-masing perlakuan minggu ke 2, 4, 6, 8 dan selama penelitian.

\begin{tabular}{cccccc}
\hline MingguKe & P0 & P1 & P2 & P3 & Ket \\
\hline 2 & 85,20 & 83,23 & 70,71 & 61,36 & ns \\
4 & 81,32 & 75,57 & 63,11 & 60,65 & ns \\
6 & 74,80 & 80,40 & 69,85 & 61,79 & ns \\
8 & 66,57 & 74,20 & 75,41 & 71,81 & ns \\
\hline Rataan & 76,97 & 78,35 & 69,77 & 63,90 & $\mathrm{~ns}$ \\
\cline { 2 - 6 } Sd & 8,16 & 4,20 & 5,07 & 5,29 & \\
\hline
\end{tabular}

Keterangan: $\mathrm{P} 0=$ ransum kontrol, $\mathrm{P} 1=$ Penggunaan $1,5 \%$ TDK dalam ransum. $\mathrm{P} 2=\mathrm{Penggunaan} 3 \%$ TDK dalam ransum dan $\mathrm{P} 3=$ Penggunaan $4,5 \%$ TDK dalam ransum. $\mathrm{ns}=$ tidak berpengaruh nyata $(\mathrm{P}<0,05)$. 


\section{Tebal Kerabang}

Rataan tebal kerabang selama penelitian dapat dilihat pada Tabel 9.

Tabel 9. Rata-rata tebal kerabang telur pada masing-masing perlakuan minggu ke 2, 4, 6, 8 dan selama penelitian.

\begin{tabular}{ccccccc}
\hline Minggu Ke & P0 & P1 & P2 & P3 & Ket & satuan \\
\hline 2 & 0,38 & 0,39 & 0,40 & 0,38 & $\mathrm{~ns}$ & $\mathrm{~mm}$ \\
4 & 0,37 & 0,37 & 0,37 & 0,37 & $\mathrm{~ns}$ & $\mathrm{~mm}$ \\
6 & 0,38 & 0,38 & 0,38 & 0,37 & $\mathrm{~ns}$ & $\mathrm{~mm}$ \\
8 & 0,36 & 0,36 & 0,38 & 0,35 & $\mathrm{~ns}$ & $\mathrm{~mm}$ \\
\hline Rata-rata & 0,37 & 0,37 & 0,39 & 0,37 & $\mathrm{~ns}$ & $\mathrm{~mm}$ \\
\cline { 2 - 7 } Sd & 0,01 & 0,01 & 0,01 & 0,01 & & \\
\hline
\end{tabular}

Keterangan: $\mathrm{P} 0=$ ransum kontrol, $\mathrm{P} 1=$ Penggunaan $1,5 \%$ TDK dalam ransum. $\mathrm{P} 2=$ Penggunaan $3 \%$ TDK dalam ransum dan $\mathrm{P} 3=$ Penggunaan $4,5 \%$ TDK dalam ransum. $n s=$ tidak nerbeda nyata $(\mathrm{P}>0.05)$.

Hasil analisis ragam menunjukkan penggunaan tepung daun kelor berpengaruh tidak nyata $(\mathrm{P}>0.05)$ terhadap tebal kerabang. Nilai rataan tebal kerabang selama penelitian yaitu $\mathrm{P} 0 \quad(0,37 \pm 0,01), \mathrm{P} 1 \quad(0,37 \pm 0,01), \mathrm{P} 2$ $(0,39 \pm 0,01)$, dan P3 $(0,37 \pm 0,01)$. Penggunaan tepung daun kelor berpengaruh tidak nyata terhadap tebal kerabang disebabkan jumlah kandungan kalsium pada ransum tidak berbeda jauh, namun tebal kerabang masih tergolong kedalam kualitas yang baik, sesuai pendapat Soeparno et al., (2011) bahwa tebal kerabang yang baik untuk dipasarkan adalah 0,3-0,33 $\mathrm{mm}$ sehingga tidak mudah pecah.

Tebal tipisnya kerabang telur dan kualitas dari kerabang telur tergantung pada jumlah kalsium yang terdapat pada pakan (Stadellman et al., 1995). Menurut Analysa (2007) daun kelor mengandung kalsium empat kali lebih banyak dibanding susu. Kerabang telur memiliki peranan penting untuk melindungi telur dari mikroorganisme sehingga menurangi pembusukan (Tjahjadi dan Herlina, 2011).

\section{KESIMPULAN}

Berdasarkan hasil penelitian dapat disimpulkan bahwa penggunaan tepung daun kelor dalam ransum sampai level 4,5\% dapat meningkatkan skor yolk, semakin tinggi penggunaan dalam ransum semakin meningkat skor yolk. Penggunaan tepung daun kelor pada ransum $1,5 \%, 3 \%$, dan $4,5 \%$ tidak mempengaruhi berat telur, berat yolk, indeks yolk, indeks albumen, haugh unit dan tebal kerabang telur ayam ras petelur coklat dari umur 20 bulan.

\section{DAFTAR PUSTAKA}

Amrullah, I.K. 2003. Nutrisi Ayam Petelur. Bogor (ID) : Satu Gunungbudi.

Analysa, L. 2007. Efek Penggunaan Tepung Daun Kelor (Moringa oleifera) dalam Pakan Terhadap Berat Organ Dalam, Glukosa Darah dan Kolesterol Darah Ayam Pedaging. Fakultas Peternakan Universitas Brawijaya Malang.

Anggoridi, R.1997. Ilmu makanan Ternak Umum. Pt. Gramedia, jakarta

Argo, L. B. dan Mangisah. 2013. Kualitas Fisik Telur Ayam Arab Petelur Fase 1 Dengan Berbagai Level Azolla Microphylla Animal Agricultural Journal. 2(1): 445-457

Austic, R. E. and M. C. Nesheim. 1990. Poultry Prodution. $4^{\text {th. }}$ Edition. Lea and Febiger.

Banjo, O. S. 2012. Growth and Performance as Affected by Inclusion of Moringa oleifera Leaf Meal in Broiler 
Chicken Diet. J. Biol. Agric. Healthcare, 2: 35-38.

Bhale S, H. K. No, W. Prinyawiwatkul, A.J. Farr, K. Nadarajah, and S.P. Mayers. 2003. Chitosan CoastingImproves Shelf Life of Eggs. J Food Sci 68: 2378-2383.

Buckle, K. A., R. A. Edward, G.H. Fleet, M. Wotton. 1987. Food Science. Australia Vice Chancellorst Commite. Sidney.

Hartadi, H., S. Reksohadiprodjo dan A. D. Tilman. 2005. Tabel Komposisi Pakan Untuk Indonesia. Gadjah Mada University Press. Yogyakarta .

Koswara, S. 2009. Teknologi pengolahan telur (teori dan praktek). EBookPangan. Com. Diakses 25 Desember 2016.

Krisnadi, A.D. 2015. Kelor Super Nutrisi. Blora Pusat Infromasi dan PengembanganTanaman Kelor Indonesia. Blora (ID): Pusat Informasi dan Pengembangan Tanaman Kelor Indonesia, Lembaga Swadaya Masyarakat- Media Peduli Lingkungan.

Misra, A., Srivastava, S., and Srivastava, M. (2014). Evaluation of anti diarrheal potential of Moringa oleifera (Lam.) leaves. Journal of Pharmacognosy and Phytochemistry. 2(5), 43-46.

North, M.O. and D. Bell. 1990. Commercial chicken production manual. United States of America (US): Incorporate.

Nowland, W. J. 1987. Modern Poultry Management in Australia. The $2^{\text {nd }}$ Edition Limited Adelaide, Sydney.

Romanoff, A. L. and A.J. Romanoff. 1963. The Avian Egg. John Wiley and Sons Inc,. New York.

Saliem, H. P., E. M. Lakolo, T. B. Purwantini, M. Ariani dan Y. Marisa . 2001. Analisis Ketahanan Pangan Tingkat Rumah Tangga dan Regional.
Laporan Hasil Penelitian. Pusat Penelitian Dan Pengembangn Sosial Ekonomi Pertanian . Bogor.

Sari N. 2017. Efektivitas Tumbuhan Obat Sebagai Pengganti Feed Additive Komersial. Jurusan Peternakan. Fakultas Pertanian. Universitas Bengkulu.

Sarjono, H. T. 2008. Efek Penggunaan Tepung Daun Kelor (Moringa oleifera, Lam) dalam Pakan terhadap Persentase Karkas, Persentase DeposisiDaging Dada, Persentase Lemak Abdominal Dan Kolesterol Daging Ayam Pedaging. Fakultas Bioteknologi. Universitas Atma Jaya. Yogyakarta.

Sarwono, B. 2001. Pengawetan dan Pemanfaatan Telur. Penebar Swadaya, Jakarta.

Simbolon, J. M. M. Simbolan. N. Katharina. 2007. Cegah Malnutisi dengan Kelor. Yogyakarta: Kanisius

Sjofjan, O. 2008. Efek penggunaan tepung daun kelor (Moringa oeifera) dalam pakan terhadap penampilan produksi ayam pedaging. Seminar Nasional Teknologi Peternakan dan Veteriner, Bogor.

Soekarman dan Riswan, S. 1992. Status Pengetahuan Etnobotani di Indonesia. Perpustakaan Nasional RI dan Litbang Botani, Puslitbang LIPI, Bogor, Dalam Prosiding Seminar dan Lokakarya Nasional Etnobotani, Cisarua, Bogor, 19-20 Februari LIPI dan Lembaga Perpustakaan Nasional RI. Hal. 1-7.

Soeparno, R., A. Rihastuti, Indratingsih dan S. Triatmojo. 2011. Dasar TeknologiHasil Ternak. Fakultas Peternakan. Universitas Gadjah Mada. Yogyakarta.

Stadelman, W. J, and O. J. Cotteril. 1995. Egg Science and Techonology. Fourt Ed Food Product Press. An Imprint of 
the Haworth Press. Inc. New York, London.

Standar Nasional Indonesia nomor 01-39262006. Telur Ayam Konsumsi. Badan Standar Nasional, Jakarta.

Sudaryani, T. 2006. Kualitas Telur. Penebar Swadaya, Jakarta.

Suhada. 2016. Pengaruh Penggunaan Daun Kelor (Moringa oeifera) dan Asam Fulvat Terhadap Kualitas Telur Puyuh. Departemen Ilmu Nutrisi dan Teknologi Pakan. Fakultas Peternakan. Institut Pertanian Bogor.

Sujana, E., S. Wahyuni, H. Burhanuddin. 2006. Efek Pemberian Ransum Yang
Mengandung Tepung Daun Singkong, Daun Ubi Jalar Dan Eceng Gondok Sebagai Sumber Pigmen Karotenoid Terhadap Kualitas Kuning Telur Itik Tegal. J IlmuTernak. 6(1):53-56.

Triyuanta. 1998. Pengaruh Berat Badan Inisial dan Model Distribusi Pakan Terhadap Hirarkis Folikuler dan Persintesi Produksi Ayam Petelur. Bulletin Peternakan. 22 (1): 14-24.

Triyuanta, B. 2002. Telur dan Produksi Telur. Fakultas Peternakan. Universitas Gadjah Mada. Yogyakarta.

Wahyu, J.1997. Ilmu Nutrisi Ungags. Universitas Gadjah Mada. Yogyakarta. 